\title{
Kurikulární reformy $v$ anglofonních zemích: tři případy proměny historického učiva v primárním vzdělávání ${ }^{1}$
}

\author{
Dominik Dvořák, Michaela Dvořáková \\ Univerzita Karlova, Pedagogická fakulta
}

\begin{abstract}
Abstrakt: $\vee$ probíhajících diskusích o revizi kurikula se jeví jako klíčová otázka místa faktických znalostí v učivu a jejich vztah ke konceptuálnímu porozumění. $V$ této studii popisujeme a porovnáváme možná řešení na př́kladech př́istupu k historickému učivu v primární škole v kurikulárních dokumentech tří zemí. Pro analýzu jsme zvolili Austrálii, Anglii a Spojené státy americké, nebot' $v$ těchto zemích byla $v$ posledních asi pěti letech vytvořena či revidována kurikula nebo standardy. Naše analýza ukazuje určité společné trendy: ve sledovaných zemích dochází k centralizaci a podrobnějšímu určování obsahu kurikula, na historii, zejména národní, se ve škole klade obnovený důraz. V primární škole se doporučuje určitý návrat k chronologickému přehledu a pojetí dějin jako příběhu. Odlišně jsou však řešeny právě otázka faktických znalostí a také návaznost učiva výuky primární a sekundární školy (lineární versus cyklické osnování).
\end{abstract}

Kličová slova: kurikulum, dějepis, vlastivěda, srovnávací pedagogika

\section{Curriculum Reforms: Primary History Change in Three English-Speaking Countries}

Abstract: Central to contemporary revisions of curriculum are the questions of the relationship between factual and conceptual knowledge. In this paper we describe and compare the national curricular frameworks or content standards for primary history in three countries. Australia, England and United States of America are chosen as our sample as these countries recently revised their national frameworks, issued the new ones or the revision is under way. Our analysis shows some common trends: the increased centralisation and prescription in curricular policy, growing emphasis on (national) history in schools, return to chronological overviews and narration in primary history. The analysed documents, however, differ in the way how the factual knowledge is included and in relationship of primary to secondary history teaching (linear vs. cyclic).

Keywords: curriculum, school history, social studies, comparative education

V současné době v České republice probíhá revize rámcových vzdělávacích programů (RVP). Je proto žádoucí, abychom měli k dispozici aktuální informace jak o procesních, tak obsahových aspektech zahraničních kurikulárních reforem a o odborných diskusích, které je doprovázejí. Srovnáváme proto nedávný vývoj kurikula ve třech anglofonních zemích na príkladu projektování dějepisného učiva pro primární školu. ${ }^{2}$ Chceme tím přispět $k$ zaplnění určité mezery $v$ našich znalostech o tom, jak se ve

1 Text vznikl s podporou grantu GA ČR „Nadnárodní trendy v kurikulu školního vzdělávání a jejich působení v národním vzdělávacím systému“ (15-25137S).

2 Primární školou rozumíme úroveň vzdělávání ISCED 1, viz př́loha A. 
136 světě vyvijí pojetí historického učiva, které bývá u nás součástí integrovaného předmětu vlastivěda (popř. člověk a jeho svět). ${ }^{3}$ Dalším cílem je upozornit na obecnější diskusi o místě různých typů znalostí ve vzdělávání (Young, 2007).

\section{Teoretická východiska}

Otázkám výběru a uspořádání učiva není v současné pedagogice věnována velká pozornost. Podle Peškové et al. (2014, s. 10) patří cíle a obsahy do staršího pojetí kurikula, zatímco „moderni“ pojetí, které označují jako netechnické, „se odvrací od tradičního projektování kurikula“ a zabývá se více otázkami filozofickými, sociálními apod. Zároveň však uvedení autoři uvádějí názor $M$. Younga, že takový přesun důrazu je spiše projevem krize než skutečné modernizace kurikula. Takzvaná rekonceptualizace kurikulární problematiky, jež odklonila zájem od otázek konstrukce osnov, se nám jeví spiš jako důsledek postmoderního než moderního obratu (Dvořák, 2012). Pro současné sociální vědy je nepochybně typický přesun pozornosti od výzkumu reality ${ }^{4} \mathrm{k}$ zájmu o její vnímání a prožívání aktéry. Také $v$ didaktice dějepisu se zájem výzkumníků zaměřuje na historické vědomí dětí i dospělých a obdobné konstrukty. Posiluje se tak empirický a vědecký charakter oborové didaktiky a brání to její redukci na metodiku (Beneš \& Gracová, 2015; Činátl, Pinkas, et al., 2014; Labischová, 2013).

Patř́i však k podstatě pedagogických věd, že se nemohou zcela vzdát normativních úkolů, jinak by byl výběr cílů a obsahů vzdělávání zcela ponechán praxi (v případě primární školy učitelům bez speciálního historického vzdělání) nebo politikům. Empirický výzkum historického myšlení a vědomí žáků by ovšem měl zásadně ovlivňovat a korigovat normativní rozhodnutí o výběru a řazení učiva. Kurikulum je totiž vždy současně utvářeno vývojem „mateřské disciplíny“, v tomto případě akademické historie a historiografie (Retz, 2016), a vlivy pedagogicko-psychologickými. Pojetí dějepisného učiva pro primární školu by mělo vyrůstat z průniku poznatků o tom, co je dobrá pedagogika mladšího školního věku a současně co je dobrá výuka historie (Guyver, 2011), což odpovídá charakteristice didaktiky dějepisu jako oboru „na pomezi““ (Beneš \& Gracová, 2015, s. 297).

Na počátku tohoto století mnoho zemí při stanovení vzdělávacích cílů kladlo dưraz na kompetence žáků. Jako úkol druhé dekády se jeví nalezení vyváženého a funkčního vztahu mezi obecnými kompetencemi a oborovými znalostmi. Velké pozornosti se $v$ této souvislosti dostává programu sociálního realismu (Young \& Muller, 2010). V didaktice dějepisu byl obrat k dovednostem spojen s programem „nové historie“, kladoucím důraz na badatelské dovednosti. Ukázaly se však i jeho slabiny, podle Wilschuta (2009) nevyjádřil dostatečně specifický přínos dějepisu pro všeobecné

3 V textu dáváme přednost termínům dějepis nebo historie před tradičním označením vlastivěda, nebot' ve sledovaných zemích tak jsou vzdělávací obor či jeho př́slušné vlákno označovány již na úrovni primární školy.

4 Přidržujeme se přesvědčení o existenci intersubjektivní reality, jejíž poznávání však je vždy historicky a sociálně ovlivněno/konstruováno. 
vzdělání, nebot' do značné míry šlo o metody společné všem sociálním vědám. „Nová historie“ narážela i na řadu praktických problémů (Čapek, 2005). Didaktika dějepisu proto dnes (paralelně s historiografií) rehabilituje význam faktografie, chronologického myšlení i narace a odklání se od „bezvědomostního vyučováni““ (Labischová \& Gracová, 2010, s. 28). Americké Národní centrum pro historii ve škole (Kalifornská univerzita v Los Angeles, USA) dokonce na svém webu připomíná, že základem dětského poznávání historie je znalost faktů, jmen, dat a míst. Přes dílčí korekce však „nová historie“ zůstává dodnes podnětnou; Smith (2017) se domnívá, že předběhla svou dobu a představuje žádoucí spojení badatelských př́stupů i oborového konceptuálního myšlení v duchu sociálního realismu.

Kromě uvedených odborných vlivů se zejména $v$ případě dějepisu ukazuje také velká role politických zásahů do obsahu a pojetí vzdělávání. Zdá se, že na počátku 21. století jsou tyto zásahy zejména reakcí na procesy globalizace (at' už reálné, nebo jen subjektivně vnímané). Zakaria (2016) shrnuje, že tradiční politické síly se snaží vypořádat s důsledky globalizace, přičemž ji často chápou jako ohrožení pravice vnímá erozi (národní) identity a levice zvyšující se nerovnost mezi různými skupinami. ${ }^{5}$ Obě skupiny se pak snaží tyto (skutečné nebo vnímané) problémy řešit $\checkmark$ neposlední řadě prostřednictvím školy a jejího kurikula - v př́padě dějepisu bud' útěkem k idealizované národní minulosti a tradiční faktografii, nebo naopak radikální relativizací tradičních znalostí i hodnot (podrobněji dále). ${ }^{6}$

\subsection{Historie v primární škole}

V poslední době v českém prostření vzniklo více prací o různých aspektech školního dějepisu (Beneš, 2011; Beneš \& Gracová, 2015; Činátl, Pinkas, et al., 2014; Gracová \& Labischová, 2012; Havlůjová, Najbert et al., 2014; Labischová \& Gracová, 2010) včetně studií kurikula (Hudecová, 2006; Jireček, 2014), až na výjimky (Stará \& Starý, 2017) však zůstává stranou pozornosti výuka na 1. stupni základní školy. Přitom se veřejnost i učitelé domnívají, že dějepis je potřeba již v primární škole přiměřeným způsobem vyučovat a že by zejména ve vlastivědě měli žáci získávat „elementární poznatky o historii“ (Černý \& Šubrt, 2013, s. 65). Současně zaznívá nespokojenost s reálnou podobou výuky: „Já mám dceru ve 4. trrídě a učí se všechny křížové výpravy proti husitům! "7 Respondenti citovaného sociologického výzkumu mluví o podobném dilematu:

5 Jak krize tradiční identity, tak nárůst nerovnosti jsou možná jen různé projevy jednoho procesu rozpadu/transformace tradičních struktur společnosti. Zakaria tyto myšlenky př́ipisuje bývalému britskému ministru zahraničí D. Milibandovi.

6 V př́padě historie navíc byl dosavadní popis minulosti označován za príliš jednostranně zdůrazňující perspektivu držitelů moci, mužů, euroamerické civilizace apod. Postmoderní dekonstrukce měla nepochybně velký dopad právě na historii a dějepis. Dnes se ovšem ukazuje, že teze o konci velkých vyprávění je možná jen dalším z těchto velkých vyprávění.

7 Citovaný výrok vyslovil středoškolský učitel a oborový didaktik T. Mikeska v diskusi o výuce dějepisu (Štorchưv..., 2013, s. 217). Nelze se ubránit myšlence, že historici, didaktici i učitelé z vyšších stupňu škol zintenzivní zájem o výuku v primární škole, až když jim vlastní děti dorostou do věku školní docházky. 
Výuka by se měla nějak vypořádat s rozporným faktem, že člověk si musí na jedné straně osvojit rozsáhlou sumu jmen a letopočtů, na druhé straně ale musí událostem porozumět, pochopit je. Často se zdá, jako by tyto dva požadavky směřovaly proti sobě. Když např. učitel žáky zahltí daty a podrobnostmi, nezbude mu už čas na to, aby dějiny také vyložil. (Černý \& Šubrt, 2013, s. 62)

Učitelé dějepisu na vyšších stupních se musejí vyrovnat nejen s osobním a rodinným proživáním minulosti svých žáků a s historickými (dez)informacemi z řady dalších zdrojů (Beneš \& Gracová, 2015; Mareš, 2017), ale také s pojetími a interpretacemi předanými žákům učiteli 1 . stupně. Proto ve studii hledáme, jak novější zahraniční kurikula vymezují po obsahové i formální stránce obsah dějepisného vyučování v primární škole, jak se řeší vztah mezi poznáváním historických faktů, rozvíjením konceptuálního porozumění a oborovými dovednostmi, ale také jak reagují na novou vlnu nacionalismu (Symcox \& Wilschut, 2009). Zatímco Stará a Starý (2017) se výukou historie u mladších žáků zabývají v mikroperspektivě školní třídy, zde se tedy zaměřujeme na makroúroveň kurikulární politiky a př́slušné dokumenty.

$\checkmark$ zahraniční literatuře existují práce, které se analyticky či kriticky zabývají vývojem kurikula (primárního) dějepisu v jedné z námi sledovaných zemí (Guyver, 2011; Labadie, 2011; Ross, Mathison, \& Vinson, 2015; Smith, 2017 aj.) i práce komparativní (De Groot-Reuvekamp et al., 2014; Harris \& Ormond, 2018; Savage \& O’Connor, 2015). Jejich autoři mívají oproti nám výhodu, že pí̌̌ou o domácí situaci, kterou důvěrně znají. My se však $v$ této práci zaměřujeme na kurikula, která vznikla, výrazně se měnila nebo mění v posledních pěti letech, takže v odborné literatuře jsou dosud jen málo reflektovaná. Předností studie může tedy být aktuálnost informací. I když její rozsah neumožnil podrobnější srovnání s českým kurikulem, při volbě tématu i výběru prezentovaných informací jsme přihližželi k české situaci.

Základní výzkumné otázky jsou: Jak politický kontext ovlivňuje proces tvorby a revize kurikula? Jak se mění postavení dějepisu v primárním kurikulu? Jaké je současné pojetí obsahu historického vzdělávání v primární škole?

\section{Metoda výzkumu}

Výzkumnou strategií použitou $v$ této stati je komparace procesu vzniku a výsledné podoby tři „národních“ kurikulárních dokumentů týkajících se pojetí dějepisu v primární škole. ${ }^{8}$ Přes řadu výhrad, v neposlední řadě zdůvodňovaných globalizací, hraje analýza na úrovni státu ve srovnávací pedagogice stále zásadní roli (Adamson \& Morris, 2007). Vztah státní vzdělávací politiky a nadnárodních trendů je nadále kličovým teoretickým problémem současné komparatistiky (Greger, 2015).

8 Slovo národní odkazuje $\mathrm{k}$ federální úrovni u USA a Austrálie. V Spojeném království neexistuje celostátní vzdělávací politika, termín národní je součástí oficiálního označení anglického kurikula. Je zřejmé, že $v$ jednotlivých kontextech má pojem národa odlišnou genezi i obsah, to však jde za hranice naší studie. 
Při výběru př́padů byla uplatněna tato hlediska: Jde o země, kde v posledních pěti letech vznikl nebo byl revidován národní kurikulární dokument. Dále jsme uplatnili teoretické vzorkování, aby byly zachyceny různé formy vymezení obsahu učiva primární školy (tabulka 1). Z hlediska kontextu jde o země vysoce multikulturní, které se vyrovnávají s rozsáhlou novodobou imigrací a dalšími projevy globalizace, popř. s problémem reprezentace perspektivy autochtonní populace $v$ dějepisu (např. pưvodní obyvatelé Austrálie). ${ }^{9}$

Tabulka 1 Přehled zahrnutých zemí

\begin{tabular}{|c|c|c|c|}
\hline & $\begin{array}{l}\text { Nový dokument / } \\
\text { revize }\end{array}$ & $\begin{array}{l}\text { Období probíraná } \\
\text { v primární škole }\end{array}$ & $\begin{array}{c}\text { Vztah učiva primární a (nižší) } \\
\text { sekundární školy }\end{array}$ \\
\hline Anglie & $2013-2014$ & $\begin{array}{l}\text { pravěk, starověk a raný } \\
\text { středověk }\end{array}$ & $\begin{array}{l}\text { lineární návaznost v obecných } \\
\text { i národních dějinách }\end{array}$ \\
\hline Austrálie & 2015 & přehled národní historie & $\begin{array}{l}\text { cykličnost, v primární škole lokální } \\
\text { a národní a v sekundární škole } \\
\text { obecné dějiny }\end{array}$ \\
\hline USA & 2013 & $\begin{array}{l}\text { na národní úrovni více } \\
\text { nezávazných dokumentů } \\
\text { s různými př́stupy }\end{array}$ & \\
\hline
\end{tabular}

Vycházíme z primárních pramenů - př́islušných rámcových kurikul. Pro charakteristiku a interpretaci kontextu užíváme sekundární zdroje. Cílem je popsat nejen současný stav, ale také jeho nedávné proměny, proto jde o dvojí pohled - nejdříve diachronní srovnání v rámci jednotlivých zemí, pak synchronní komparace zemí mezi sebou. Základní přístup k analýze je kvalitativní. Jednotlivé případy prezentujeme narativně, abychom zachytili procesy vzdělávací politiky, které občas postrádají (žádoucí) racionalitu. Pro každý př́pad tedy krátce vyprávíme politický „příběh“ vzniku nebo revize kurikula. Metodologie analýzy kurikulárních dokumentů - i vzhledem k značné variabilitě - není ve výzkumné praxi ustálená. Vycházíme proto z doporučení Donnellyho et al. (2005). Všímáme si nejdříve formálních vlastností dokumentu (jeho závaznost, podrobnost, další charakteristiky), postavení historie v kurikulu (např. samostatný/integrovaný předmět), logiky osnování učiva, způsobu vymezení deklarativních a procedurálních znalostí (fakta, pojmy, popř. principy versus dovednosti) a jejich vzájemného vztahu. Toto schéma je však obrysové, dáváme také prostor aspektům „vynořujícím se“ při analýze.

Ve shodě s praxí kvalitativního výzkumu uvádíme citáty z dokumentů (rozsáhlejší $z$ nich $v$ prílohách), aby si čtenář mohl naše závěry do určité míry ověřit jejich konfrontací s primárními daty. ${ }^{10}$ Výběr ukázek je podřizen výzkumné otázce zabývající

9 Německo, které na naši teorii i praxi vyučování dějepisu má tradičně významný vliv, není zahrnuto, protože nevíme o zásadní změně kurikula $v$ poslední době a dosavadní pojetí primární historie bylo již v češtině popsáno (Dvořák \& Dvořáková, 2010). Chtěli jsme zahrnout také Nizozemsko, ale proces revize kurikula dosud probíhá, viz curriculum.nu.

10 Pouze $v$ prípadě Austrálie z rozsahových důvodů je $\mathrm{v}$ príloze zkrácený a parafrázovaný dokument. Ve všech př́padech však uvádíme odkazy na webové stránky, kde jsou originální dokumenty plně dostupné. 
140 se místem faktických znalostí, nedokumentujeme proto podrobně, jak jsou vymezeny cíle $v$ oblasti procedurálních dovedností (např. práce s historickými prameny).

\section{Popis př́padů}

Případy jsou prezentovány chronologicky podle doby, do níž sahají kořeny pojetí, které je předmětem analýzy. Anglické kurikulum pochází z konce osmdesátých let 20. století, jeho poslední revize je implementována od roku 2014. V př́padě USA srovnáváme standardy výuky historie z první poloviny devadesátých let minulého století a nové rámcové standardy společenských věd z roku 2013. Australské „národni““ kurikulum bylo publikováno v roce 2010 a revidovaná „verze 8“ v říjnu 2015.

\subsection{Anglie}

Národní kurikulum (NC) pro Anglii a Wales stálo na začátku obnoveného zájmu o projektování kurikula a mělo značný vliv na vzdělávací politiku i pedagogické myšlení $\checkmark$ řadě zemí. Zde se zaměříme na výsledky nejnovější revize NC, která se dotkla zejména druhého klíčového období, jež odpovídá 3. až 6. ročníku ( $v$ Anglii žáci věku 7 až 11 let, viz príloha A). Nejprve ale charakterizujeme politický kontext.

Proces tvorby kurikula a jeho politický kontext. NC bylo dílem pravicových politiků. K první výraznější revizi kurikula došlo ještě za jejich vlády v první polovině devadesátých let minulého století zejména pod tlakem učitelů, kteří nebyli schopni zvládnout komplexní administrativu spojenou s původně zamýšleným pravidelným testováním všech předmětů. Bylo tedy rozhodnuto netestovat žáky v „ostatních“ předmětech (mezi nimi dějepis) a celkově redukovat obsah kurikula. Konzervativce $v$ letech 1997-2010 vystř́idalo dlouhé období vlád levice. Tony Blair byl prototypem nové, pragmatické tváře levicové politiky, která ve vzdělávací politice kladla důraz na základní gramotnosti. Na přelomu století tak došlo $k$ dočasnému faktickému zrušení platnosti centrálního kurikula pro ostatní předměty včetně historie, čímž se měl školám vytvořit větši prostor pro rozvoj základních dovedností v mateřském jazyce a matematice.

Další zásadní revize NC byla očekávána kolem roku 2010. Doporučení pro primární školu shrnovala Roseova zpráva dokončená v roce 2009. Podle Guyvera (2011) se $\checkmark$ anglických primárních školách dlouhodobě opět zvyšovala obliba integrace dějepisných témat $s$ jinými předměty (jak odpovídá tamější didaktické tradici). Proto se uvažovalo o nahrazení dosavadní předmětové struktury širšími vzdělávacími oblastmi. Historie, jež vystupovala v NC i v primární škole jako samostatný předmět, by se stala součástí humanitní, sociální a environmentální vzdělávací oblasti (tedy učení o člověku, společnosti a prostředí). Od roku 2010 však opět Spojenému království vládla středopravá, resp. pravicová (od roku 2015) vláda Davida Camerona, která tyto připravené podněty odmítla, provedla vlastní revizi, a upravené kurikulum pro primární školu tak vstoupilo v platnost až v roce 2014. Dějepis zůstal nadále v druhém období samostatným předmětem. 
Předchozí kurikulum. Původní pojetí historie v NC popsali Dvořák a Dvořáková (2010) pro primární školu, pro sekundární školu Hudecová (2006), celé kurikulum pak Walterová (1994).

Nové kurikulum. V novém kurikulu zůstal zachován základní princip, který omezuje spirální osnování učiva. Chronologicky uspořádaný výklad britské a světové historie nastupuje již v primární škole, na což lineárně navazuje nižši sekundární škola, která se již nevrací ke starším dějinám a zaměřuje se na britskou a světovou historii od normanské invaze. ${ }^{11} \mathrm{Z}$ tohoto pravidla existuje výjimka: primární školy dále mohou zařadit jedno období britské historie po roce $1066 .{ }^{12}$ Učivo je tedy organizováno na chronologickém principu (bez spirály), přesto se však nejedná o mechanické probírání jednotlivých období: jde spiše o sled vybraných témat, která jsou navíc rozdělena na povinná a (povinně) volitelná. Jsou tak vytvořeny podmínky pro kombinaci dvou př́stupů: žáci mají získat celkový přehled (overview) a současně hlouběji proniknout do dílčí problematiky (depth studies), jak bylo typické pro tematicky/ projektově orientovanou výuku v anglické škole ve 20 . století.

Po obsahové stránce je cílem ${ }^{13}$ dějepisného vzdělání, aby si žák kromě historických faktů osvojil jednak oborové výrazy (jako říše/impérium, civilizace, parlament, zemědělství), ale také aby porozuměl obecnějším oborovým pojmům (kontinuita a změna, přičina a důsledek, podobnost a rozdílnost...) a uměl je používat pro nalézání souvislostí, analýzu trendů či vytváření strukturovaných výpovědí včetně psaných př́běhů a analýz.

Pokud srovnáme učivo před revizí a po ní (tabulka 2), tak kurikulum je o něco málo podrobnější s cílem poskytnout žákům systematičtější chronologický přehled. Kromě závazně stanovených období jsou historická fakta vždy uvedena jako př́klady, které představují nezávazné náměty. Např́klad pro téma Proměny Británie od doby kamenné do doby železné je uveden tento možný obsah:

- pozdně neolitičtí lovci a sběrači a první zemědělci, např. Skara Brae;

- náboženství, technologie a cestování v době bronzové, např. Stonehenge;

- hradiště doby železné: kmenová království, zemědělství, řemesla a kultura.

Je nutné zdůraznit, že $v$ anglickém kurikulu vždy byla a zůstala zdůrazněna procesuální stránka učení a rozvoj př́slušných badatelských dovedností. Již původní koncepce NC na počátku devadesátých let minulého století předpokládala, že na konci klíčových období budou žáci testováni i z dějepisu, avšak nikoli ze znalosti historických faktů, ale právě z př́slušných oborových dovedností. Pro to se jeví klíčová právě rovnováha mezi přehledem a hlubším poznáním vybraných témat. Tento pří-

11 Jedním z cílů původního NC v oblasti dějepisu bylo překonat diskontinuitu, kdy $v$ důsledku odlišného pojetí školního dějepisu učiteli primárních a sekundárních škol vznikal jev označovaný jako restart: učitelé na 2. stupni přistupovali k žákům tak, jako by žádnou historickou výukou dosud neprošli. To se podle Hugginse a Knighta (1997) príliš nepovedlo.

12 Jde o reakci na velkou oblibu tématu viktoriánská Británie (resp. druhá světová válka) u učitelů i žáků primární školy, kterou dokumentovaly výzkumy historického vědomí žáků i diskuse učitelů k reformě (témata skýtají velký prostor pro projektové učení, studium dějin všedního dne, výlety, dramatizace apod.) a finální verze revidovaného dokumentu to zohlednila.

13 Jedná se o cíle předmětu obecně, ne nutně splněné již v primární škole. 
142 Tabulka 2 Historická témata v druhém období primární školy (Key stage 2) v anglickém kurikulu

\begin{tabular}{|c|c|}
\hline Před rokem 2014 & Od roku 2014 \\
\hline $\begin{array}{l}\text { Doba římského, anglosaského } \\
\text { a vikingského panování }\end{array}$ & $\begin{array}{l}\text { Proměny Británie od doby kamenné do doby železné } \\
\text { Římská ří̌e a její vliv na Británii } \\
\text { Osídlení Británie Anglosasy a Skoty } \\
\text { Zápas Vikingů a Anglosasů o anglické království do doby } \\
\text { Eduarda Vyznavače }\end{array}$ \\
\hline $\begin{array}{l}\text { Tudorovci } \\
\text { Jedno ze dvou témat: bud' } \\
\text { viktoriánské období, anebo Británie } \\
\text { po roce } 1930\end{array}$ & $\begin{array}{l}\text { Studium jednoho aspektu nebo tématu britské historie, } \\
\text { rozšiřujícího žákovskou znalost chronologie po roce } 1066\end{array}$ \\
\hline $\begin{array}{l}\text { Evropská historie - starověké Řecko } \\
\text { Jedna velká mimoevropská civilizace }\end{array}$ & $\begin{array}{l}\text { První civilizace a jejich úspěchy - přehled, kde a kdy } \\
\text { se objevují první civilizace, a hloubkové studium jedné } \\
\text { z následujících: starověký Sumer, údolí Indu, starověký } \\
\text { Egypt, čínská dynastie Šang } \\
\text { Starověké Řecko - studium řeckého života, civilizačních } \\
\text { úspěchů, vlivu na západní svět } \\
\text { Mimoevropská společnost, která kontrastuje s britskou } \\
\text { historií - poznávání jedné z následujících: raná islámská } \\
\text { civilizace, včetně studia Bagdádu kolem roku 900; } \\
\text { mayská civilizace kolem roku } 900 \text {; Benin (západní Afrika) } \\
\text { zhruba } 900-1300 \text { n. l. }\end{array}$ \\
\hline
\end{tabular}

Téma z lokální historie - jak se Studium lokální historie měnil z dlouhodobého hlediska určitý aspekt života lidí

stup se snaží na jedné straně „rozvinout chronologicky ukotvené poznání minulosti“ zakládající „jasné př́běhy (narativy) jak v rámci studovaných období, tak i napřič nimi“ (Department for Education, 2013); a současně vytvářet prostor pro poznávání metod historického bádání a rozvoj příslušných porozumění. Školní inspekce se v poslední době zaměřuje na zjišt'ování chronologického porozumění žáků primární školy, všímá si (ne)prítomnosti časových os na stěnách učeben a opakovaně připomíná, že dobré či výtečné procesy i výsledky učení podle ní jsou tam, kde je již na 1. stupni dějepis vyučován samostatně (Maddison, 2014).

Je zajímavé, že první vládní návrh revize historického kurikula (jaro 2013) šel výrazně dál v preskripci závazného obsahu a v důrazu na faktografii. Odborná veřejnost však byla úspěšná v jeho kritice a dosáhla vyváženějšího výsledného znění. Smith (2017) na základě analýzy veřejného diskurzu uvádí, že rozhodující roli sehrály schopnost odpůrců revize rychle přejít od první emotivní reakce k věcné argumentaci a zejména existence silné odborné společnosti (Historical Association), která dokázala koordinovat kritickou diskusi a vystupovat jako jednotný zástupce různých aktérů. 


\subsection{Spojené státy americké}

Americká kurikula (na rozdíl od britských) nebyla v české odborné literatuře příliš reflektována. Zřejmě to souvisí s dřivější důslednou decentralizací kurikulární politiky v USA a absencí závazných celostátních dokumentů.

Proces tvorby kurikula a jeho politický kontext. Od osmdesátých let 20. století se role federální vlády ve vzdělávací politice stále zvyšovala a $k$ dílčí změně tohoto trendu došlo až v závěru druhého funkčního období prezidenta Baracka Obamy. Podobně jako v Austrálii, nejdříve šlo o snahu vlády formulovat na národní (tj. federální) úrovni malý počet velmi obecných cílů, z nichž by vycházela modelová kurikula, resp. standardy vytvářené na úrovni jednotlivých států federace. Důležitou úlohu sehrály v roce 1989 průkopnické, byt' kontroverzní Curriculum and Evaluation Standards for School Mathematics, které vznikly iniciativou profesního sdružení učitelů mimo oficiální vládní orgány. To vyvolalo vlnu obdobných dokumentů pro další předměty, které vytvářely rozličné skupiny a instituce. Tak vznikla i sada čtyř rámcových dokumentů pro historii, kterou tvořily standardy historického učiva pro mladší žáky (předškolní až 4. ročník); dále standardy historie USA; světové historie a historického myšlení (National Center for History in the Schools, 1994). Pokus získat oficiální podporu amerických zákonodárců pro tyto doporučené celostátní standardy skončil $\checkmark$ roce 1995 fiaskem, nebot' návrh byl jako př́liš multikulturní smeten (Labadie, 2011). Naplno se zde projevil fenomén „válek o kurikulum“ a neúspěch standardů dějepisu předznamenal ústup od snah o národní kurikulární dokumenty ve všech oborech na celou dekádu.

Konflikt mezi globální tendencí k srovnatelnosti výkonů žáků a odporem k centralizovanému kurikulu byl v posledních letech řešen tím, že celostátní kurikulum je prezentováno jako „zespodu“ vyrůstající společný projekt států. Od roku 2010 jsou takto vyvíjeny společné státní standardy (Common Core State Standards, CCSS), jejichž deklarovaným cílem je připravit co největší počet žáků ve všeobecném vzdělávání (od předškolního do 12. ročníku) pro další studium a pracovní dráhu (college \& career readiness), což je konkretizováno zejména jako schopnost dostát požadavkům úvodních kurzů počátečních ročníků vysoké školy. CCSS ovšem byly vytvořeny jen pro „jádrové“ předměty - jazykovou výchovu a matematiku. Obsahují sice doporučení, jak má probíhat rozvoj gramotnosti v ostatních předmětech, ale to lze chápat také tak, že se humanitní a společenskovědní předměty dostávají do podřízené role a mají především sloužit rozvíjení základních gramotností (či podle kritiků spiś dobrých testových výsledků). Au (in Ross et al., 2015) mluví o tom, že dřívější kurikula vymezovala „čistě jen vědomosti“, zatímco dnes se zaměřují na „čisté dovednosti“.

V dalších vzdělávacích oblastech jsou na národní úrovni modelové kurikulární materiály vytvářeny organizacemi stojícími formálně mimo vládu. Zejména oblast prírodních a technických věd se $v$ posledních letech stává politickou prioritou srovnatelnou s gramotnostmi a vývoj kurikulárních materiálů i jejich implementace jsou 
144 de facto z federálního rozpočtu financovány. Tak vznikly nové standardy pro prírodovědné předměty (Dvořák, 2015).

Předchozí kurikulum. Dnešní pohled na čtvrt století starý (oficiálně nepřijatý) standard ukazuje podle našeho názoru jeho obsahovou modernost (tabulka 3). Po formální stránce jde o víceúrovňový dokument, kde čtyřem hlavním tématům (proměny života rodiny a komunity, historie státu, historie USA, vybrané aspekty ze světových dějin společnosti, vědy a techniky) odpovídá osm hlavních standardů, které se dále člení na dílči standardy a konkretizované výstupy. Standard je doplněn řadou modelových vyučovacích lekcí a dalších materiálů pro učitele. Vedle něj však existují jednotlivé státní standardy pro společenské vědy, ale i nezávislé „národni““ standardy pro jiné obory (geografii, ekonomii...) a pro integrovaný předmět společenské vědy jako celek, rovněž se vyslovující k historii jako jednomu z vláken (viz níže).

Tabulka 3 Ukázka ze staršího standardu historie pro primární školu (National Center for History in the Schools, 1994)

Standard 7B: Žák rozumí velkým světovým pohybům lidí nyní a v dávných dobách.

\begin{tabular}{|c|c|}
\hline Ročník & Dokáže... \\
\hline 3. -4 . & $\begin{array}{l}\text { Vyhledat na mapách a vysvětlit př́ípady migrace velkých skupin - jako pohyb předků } \\
\text { původních obyvatel Ameriky přes suchozemský most v Beringově úžině, migraci Bantu } \\
\text { v Africe, pohyb Evropanů a Afričanů na západní polokouli, exodus vietnamských } \\
\text { „uprchlíků na člunech“, Hait’anů a Kubánců v posledních desetiletích. [Dovednost: } \\
\text { získávat historické informace] }\end{array}$ \\
\hline $0 .-4$. & $\begin{array}{l}\text { Na základě historických př́běhů uvést první objevitele a cestovatele jako Marco Polo, } \\
\text { Čeng Che (Zheng He), Erik Rudý, Kryštof Kolumbus. Popíše, jaké znalosti jejich cesty } \\
\text { přinesly. [Dovednost: využívat představivost při čtení historických příběhů] }\end{array}$ \\
\hline $0 .-4$. & $\begin{array}{l}\text { Na základě historických př́běhů uvést evropské objevitele } 15 \text {. a } 16 \text {. století, vysvětlit } \\
\text { důvody jejich výprav, znalosti jejich cestami získané a co se stalo v důsledku jejich } \\
\text { cest. [Dovednost: získávat historické informace, využívat představivost při čtení } \\
\text { historických př́běhů] }\end{array}$ \\
\hline $0 .-4$. & $\begin{array}{l}\text { Shromáždit informace potřebné k vysvětlení dopadu šíření zemědělských plodin } \\
\text { a zviřat mezi západní a východní polokoulí po Kolumbových cestách. [Dovednost: } \\
\text { získávat historické informace] }\end{array}$ \\
\hline
\end{tabular}

Pozn.: V hranatých závorkách odkazy na Standard historického myšlení. Nulou označujeme předškolní ročník.

Nové kurikulum. Iniciativa na poli historie a sociálních věd zůstává v rukou nevládních organizací, akademických pracovišt' a profesních sdružení. Národní rada pro společenskovědní předměty nedávno představila koncept připravenosti pro studium, pracovní dráhu a občanství ( $3 C$ - college, career, citizenship) a navrhla př́slušný kurikulární rámec společenských věd jako východisko pro kurikula jednotlivých států Unie (National Council for the Social Studies, 2013). Rámec se zaměřuje pouze na pojmy, dovednosti a oborové nástroje. Neuvádí historická fakta. Zastřešujícím konceptem je badatelský oblouk (inquiry arc) propojující čtyři dimenze poučeného zkoumání v sociálních vědách: 
1. tvorba otázek a plánování bádání;

2. použivání oborových nástrojů a pojmů;

3. shromažd’ování a hodnocení pramenů, vytváření hypotéz a užívání dokladů;

4. sdělování a kritické posuzování závěrů, informované jednání.

Obecné schéma (metaoborové dovednosti) společné všem sociálním vědám však vyžaduje i oborová porozumění a dovednosti, které jsou v $3 C$ zvlášt' rozpracovány pro občanskou výchovu, ekonomii, zeměpis a dějepis. Doplněk základního rámce jej rozšiřuje o psychologii, sociologii a antropologii. Za hlavní oborové pojmy/nástroje pro historii jsou považovány (a) změna, kontinuita a kontext; (b) perspektivy; (c) historické prameny a doklady; (d) příčinná souvislost a argumentace (přiloha B).

Dokument tak klade hlavní důraz na progresi (vývojové kontinuum) oborového porozumění a př́ślušných dovedností. Absence obsahů je dána pravděpodobně především politickými důvody: po počáteční shodě obou hlavních politických stran na podpoře CCSS se situace změnila a část pravicových politiků začala celonárodní standardy označovat za projev rostoucího zasahování federální vlády do tradičních kompetencí jednotlivých států. Zdá se logické, že při špatných předchozích zkušenostech $s$ dějepisem $v$ této atmosféře tvůrci rámcového dokumentu specifikaci obsahů ponechali státům nebo školám.

\subsection{Austrálie}

V Austrálii ústava tradičně svěřovala jednotlivým státům federace do kompetence kurikulum i ověřování vzdělávacích výsledků. Přesto lze pozorovat od osmdesátých let 20. století snahu tehdejších labouristických vlád o vytvoření národního kurikula.

Proces tvorby kurikula a jeho politický kontext. V roce 1993 byly vytvořeny $\mathrm{Na}$ tional Curriculum Statements and Profiles jako velmi minimalistický společný jmenovatel. Argumentace odpovídala globálním trendům doby - vzdělávání se mělo zaměřit na rozvoj lidského kapitálu nezbytného pro konkurenceschopnost, ale také usnadnění mobility žáků uvnitř federace. Kromě toho se bralo v úvahu, že souběžné provádění stejných činností při vývoji kurikula v mnoha federálních státech, popř. př́mo ve školách, je neefektivní (Ritzvi \& Lingard, 2010). Přesto nakonec parlament závaznou platnost dokumentu odmítl. Dlouhé období, kdy Austrálii vedli labouristé, bylo v roce 1996 vystř́idáno rovněž dlouhou vládou středopravé koalice (liberály) s politickou ideologií analogickou britským konzervativcům. Federální vláda nadále usilovala o národní systém hodnocení a standardizovaného testování, v čemž ji podporovala i opozice.

V letech 2007-2013 vládli opět labouristé, kteří před volbami slibovali „vzdělávací revoluci“ podle blairovského vzoru. $V$ úsilí o centralizaci navázali na své předchůdce (Priestley, Laming, \& Humes, 2015). V roce 2008 parlament ustavil Australský úřad pro kurikulum, hodnocení a zveřejňování výsledků (The Australian Curriculum, Assessment and Reporting Authority, ACARA).

Předchozí kurikulum. $V$ roce 2010 byl publikován vůbec první závazný národní (celostátní) kurikulární rámec pro mateřštinu (angličtinu), matematiku, př́rodní 
146 vědy a dějepis. Obsahuje tři dimenze: oborově založené vzdělávací oblasti, obecné kompetence ${ }^{14}$ neboli dovednosti pro 21 . století a tři prưřezové priority. Celkově je hodnocen jako návrat k tradičním vzdělávacím oborům/předmětům jako základu kurikula (Lingard \& McGregor, 2014). Tomu odpovídá skutečnost, že dějepis vystupoval $\checkmark$ učebním plánu jako samostatný předmět již od počátku primárního vzdělávání. Reforma zavedla rovněž plošné ověřování základních dovedností. ${ }^{15}$

Nové kurikulum. Od roku 2013 je $v$ čele federace opět koalice pod vedením pravicových liberálů. Vláda provedla revizi kurikula po formální stránce oslabující průřezová témata ve prospěch oborů. To má důsledky i pro citlivé téma zahrnutí perspektivy prvních obyvatel Austrálie (Aboridžinců) a interpretace vztahu evropských přistěhovalců k původním obyvatelům. Protože se tato perspektiva realizovala mj. formou prưřezového tématu, naplňuje se jiný ideový záměr revize, jímž je větší důraz na prínos západní civilizace (Priestley et al., 2015). Na druhou stranu v primární škole vznikl integrovaný předmět humanitní a sociální vědy, který vychází z geografie a historie a v jednotlivých obdobích postupně „přibírá“ obsah dalších disciplín (tabulka 4). Kritici se obávají, že to povede k odklonu od rozvoje specifického oborového porozumění a dovedností historického bádání a převládne důraz na znalost faktografie (Tambyah, 2015).

Řazení učiva se drží klasického modelu rozšiřujících kruhů (Bloudková-Dvořáková \& Dvořák, 2005) a chronologického výkladu národních dějin (př́loha C). Po formální stránce je zajímavé povšimnout si, že se užívá dlouhého označení integrovaného předmětu (včetně slov humanitní vědy), které však je přesnější než zahrnutí historie do sběrné kategorie „sociální vědy“ (Beneš, 2011). Po obsahové stránce se v opakovaném zdůraznění perspektivy minulost-přítomnost-budoucnost realizuje „budoucnostní rozměr historického myšlení“ (Beneš \& Gracová, 2015, s. 296). Na integrovaný předmět navazuje $v$ nižší sekundární škole dějepis zaměřený na obecné (světové) dějiny a místo Austrálie v nich.

Tabulka 4 Zastoupení humanitních a společenskovědních oborů v australském kurikulu (2010)

\begin{tabular}{|c|c|c|c|c|}
\hline Vzdělávací obor & \multicolumn{4}{|c|}{ Název předmětu v ročnících } \\
\hline & předškolní až 2. & 3. -4 & $5 .-6 . / 7$ & 7.-10. \\
\hline dějepis & humanitní & \multirow{3}{*}{$\begin{array}{l}\text { humanitní } \\
\text { a sociální vědy }\end{array}$} & \multirow{4}{*}{$\begin{array}{l}\text { humanitní } \\
\text { a sociální vědy }\end{array}$} & dějepis \\
\hline zeměpis & a sociální vědy & & & zeměpis \\
\hline $\begin{array}{l}\text { občanská nauka } \\
\text { a občanství }\end{array}$ & - & & & $\begin{array}{c}\text { občanská nauka } \\
\text { a občanství }\end{array}$ \\
\hline $\begin{array}{l}\text { ekonomika } \\
\text { a podnikání }\end{array}$ & - & - & & $\begin{array}{l}\text { ekonomika } \\
\text { a podnikání }\end{array}$ \\
\hline
\end{tabular}

14 V originálu není použit termín competences, ale general capabilities. V současném diskurzu je termín kompetence př́liš spojen s neoliberální agendou. Domníváme se však, že naše klíčové „kompetence“ odpovídají spiše obecnějšímu, humanističtějšímu pojetí capabilities, proto jsme se prìidrželi zavedeného termínu.

15 Týká se 3., 5., 7. a 9. ročníku. Rodiče mohou odmítnout testování svých dětí. 


\section{Mezipř́padová analýza: interpretace a diskuse}

Srovnáním tři popisovaných reforem či revizí kurikula nabídneme odpovědi na výzkumné otázky a naznačíme i jejich limity.

\subsection{Tendence k centralizaci}

Srovnání ukazuje, že role politického centra ve vzdělávání neklesá a ve všech sledovaných př́padech dochází k určité centralizaci kurikulární politiky. Austrálie a USA jsou federální státy, kde bylo vzdělávání tradičně silně decentralizováno, avšak $\checkmark$ obou zemích $v$ posledních letech vznikly vůbec první celostátní závazné rámce ( $v$ USA nezahrnuje dějepis). Určitou výjimkou je Spojené království, kde aktuálně probíhá proces devoluce a kde existují významné odstředivé síly. Pokud se však díváme pouze na Anglii, ani zde neklesá nastavená míra centrální kontroly a poslední revize kurikula mírně zvyšuje jeho preskriptivitu. Anglické a australské kurikulum obsahují řadu závazných prvků. Popsané americké standardy oficiální charakter nezískaly a rámec $3 C$ je nestátní iniciativou, jejiž reálný dopad na kurikulární politiku států i praxi škol nelze ještě hodnotit.

Proces tvorby kurikula nebývá přímočarý. Ve Spojených státech amerických i v Austrálii na počátku devadesátých let minulého století vznikly první návrhy společných (federálních) standardů, byly však zákonodárnými sbory odmítnuty, aby pak na konci první dekády byly znovu poměrně rychle vytvořeny ( $v$ USA jakoby zespodu) a více či méně akceptovány (Savage \& O'Connor, 2015). Kolem revize australského kurikula se rozpoutalo jedno z mnoha kol „kurikulárních válek“ (Henderson, 2015; Tambyah, 2015), předmětem sporu je tendence potlačit multikulturní, ale také oborové specifické pojetí. $V$ anglickém případě vedla změna vlády $k$ odmítnutí obou odborníky připravených revizí kurikula. Anglické NC také ukazuje, jak kurikulum již po třicet let prochází revizemi a dalšími proměnami.

\subsection{Návrat dějepisu}

Z hlediska postavení dějepisu v kurikulu a jeho zaměření můžeme v posledních dekádách pozorovat dva protikladné trendy. Nejdřive docházelo $k$ marginalizaci, později k opětovnému růstu významu dějepisného vzdělávání. Od osmdesátých let minulého století se vzdělávací politiky nejvyspělejších zemí orientovaly na dosažení ekonomické a technologické superiority. Do centra pozornosti se dostávaly především základní gramotnosti a přírodní vědy. Vlivná reforma kurikula v Anglii a Walesu (Walterová, 1994) rozdělila školní předměty na jádro (core) zahrnující mateřštinu, matematiku a př́rodní vědy, a méně významné ostatní předměty společného základu (foundation), kam byla zařazena i historie. ${ }^{16}$ Od přelomu tisíciletí takovýto hierarchický po-

16 M. Thatcherová původně pro dějepis vůbec nechtěla národní kurikulum (Ježková, Dvořák, \& Chapman, 2010). 
148 hled na vzdělávací oblasti posilují mezinárodní organizace (zejména OECD) a jejich šetření vzdělávacích výsledků. ${ }^{17}$

Současně se však stává zřejmým, že se dějiny nezredukují na hospodářské soutěžení liberálních demokracií. Nové výzvy v podobě migrace a nezdaru integrace etnických a náboženských menšin vrátily humanitní obory do hry. Zvlášt' citlivě je vnímána vına teroristických útoků, jejichž pachateli se v poslední době stávají občané západních zemí, často děti imigrantů, které již vyrůstaly a získaly vzdělání v nové vlasti, popř́padě dokonce konvertité z řad autochtonní populace. Ani v našem regionu postsocialistická transformace zatím nevede $\mathrm{k}$ lineární konvergenci mezi západem a východem Evropy: pozorujeme trvající, nebo dokonce narůstající hospodářské rozdíly, snahu zvrátit integrační procesy, vzestup nacionalismu a autoritářství. Uvedené události vyvolaly v celém světě nový zájem o formování identity - at' už evropské, národní, či regionální - prostřednictvím školního dějepisu.

Skutečnost, že politici berou znovu historii vážně, pro pojetí předmětu ve škole nemusí přinášet jen výhody a znamenat krok vpřed (Van der Leeuw-Roord, 2007). ${ }^{18}$ Při reformách kurikula se právě dějepis (resp. jeho konkrétní faktografická náplň) stává nejčastějším předmětem „kurikulárních válek“ (Schoenfeld, 2004), nebot’ se týká citlivých otázek národní identity a jeho učivo je laikům zdánlivě srozumitelné. ${ }^{19}$ Od dějepisu se (opět) očekává, že bude formovat jednotnou národní identitu a loajalitu v miře, která nemusí být slučitelná s tím, jak chápe své poslání sama historická věda i jaké cíle a prostředky oboru vytyčuje nebo empiricky nachází jeho didaktika (Symcox \& Wilschut, 2009). Přesto nadále politici mají a budou mít poslední slovo při určování kurikulární politiky. Dalši aktéři (akademická pracoviště, profesní sdružení učitelů, neziskové organizace...) se mohou snažit př́ípadné excesy korigovat. Avšak i ve vyspělých demokraciích, kterými jsme se zabývali a kde lze mluvit o lepších podmínkách pro odbornou práci historiků i oborových didaktiků (danou již prostou kvantitou př́slušných pracovišt' a týmů), bývají výzkumná zjištění a na nich založená doporučení málo využívána či zcela ignorována, přičemž vzdálenost mezi akademickou sférou a praxí se spiš prohlubuje (Brundrett, 2015). Možná k tomu přispívá i programový nezájem části pedagogů o otázky konstrukce kurikula (viz úvod). Pozornost si zde zaslouží případ Anglie, kdy úspěšnou rezistenci vůči politickému zásahu umožnila schopnost historiků přejít ke strukturované diskusi a zejména existence silné odborné společnosti zastupující zájmy odborníků i učitelů.

Otevřenou zůstává otázka, zda (a odkdy) vyučovat dějepis jako samostatný předmět či zda jej zahrnovat do širších vzdělávacích oblastí. Historie navíc není typickou sociální vědou, mezi něž bývá v kurikulech integrována (Beneš, 2011), a její mateřská disciplína se nyní opět vrací ke svým humanitním kořenům. Trvalé napětí mezi integrovaným tematickým versus oborovým př́stupem vidíme v Anglii, kde

17 Z nadnárodních aktérů byla výuka dějepisu naopak podporována např. Radou Evropy.

18 Konkrétně to ilustrují státní zásahy do kurikula dějepisu $\vee$ Rusku i dalších postkomunistických zemích (Zajda, 2015).

19 Obnovený zájem o dějepis neznamená pokles důrazu např. na předměty STEM, kde se předmětem kurikulárních válek stává matematika (Priestley et al., 2015), viz i český „spor o Hejného“. 
nyní inspekce doporučuje oborové pojetí výuky. V Austrálii naopak došlo k integraci

předmětů. Autory revize $\mathrm{k}$ tomu vedla snaha omezit roztř́štěnost vzdělávacího plánu a nepřehlednost velkého počtu cílů spíše než ontologické či gnozeologické důvody. Užívá se zde explicitního označení humanitní a sociální vědy. Čerstvá přehledová studie Levstikové a Thorntona (2018) také uvádí argumenty pro integrované pojetí. Avšak i $\vee$ prípadě integrované disciplíny (Austrálie, USA) je v kurikulu zřetelné samostatné historické vlákno (strand) a zdůrazňuje se promyšlený výběr témat a porozumění specifickým oborovým pojmům i způsobům myšlení a bádání. Nezbytná schopnost multidisciplinárně řešit problémy světa vyrůstá totiž z hluboké oborové znalosti a jednotlivé obory jsou pro ni prrínosem díky své různosti.

\subsection{Pojetí dějepisu v primární škole}

Pokud jde o pojetí učiva na 1 . stupni, pozorujeme částečný návrat k chronologickému a narativnímu př́stupu. Probíhá opatrně, protože př́liš připomíná minulé a překonané pojetí, kdy byly mladším žákům vyprávěny moralizující příběhy či předkládány seznamy jmen a letopočtů. Nejde ani o prostý návrat k memorování faktů. Ve skutečnosti je struktura (historického) vědění složitější a do znalostní báze oborového myšlení jsou zahrnovány také pojmy a konceptuální modely (např. periodizace), které vnášejí rád do faktografie. Je zdůrazněn význam historického porozumění, orientace $v$ historickém čase, konceptů „druhého řádu“ jako kontinuita, změna, kauzalita atd. Pevnou součástí výuky zůstávají oborové dovednosti historického bádání. Uvedené klíčové cíle originálně kombinuje anglické kurikulum, když vytváří podmínky jak pro chronologickou syntézu, tak pro tematický a badatelský prístup $\mathrm{k}$ vybraným obdobím, regionům a jevům.

Přestože didaktika dějepisu jako vědní obor někdy zpochybňuje, že by v globálním světě měla hrát centrální úlohu národní perspektiva, revidovaná kurikula kladou právě na národní dějiny obnovený důraz. Symcoxová a Wilschut (2009) však soudí, že se při tom někdy účelově směšuje didaktické doporučení, aby si žáci již od primární školy konstruovali referenční chronologický rámec, a politický požadavek, aby jádrem dějepisné výuky byla kanonická národní historie.

Vztah mezi výukou historie v primární a sekundární škole je řešen různým způsobem. Anglie má kurikulum lineární, nespirální. Australský rámec je cyklický - v primární škole klade důraz na lokální a národní dějiny, v sekundární škole probírá světové dějiny s přihlédnutím $\mathrm{k}$ australské situaci. Nejnovější americký rámcový materiál převážně z politických ohledů nespecifikuje obsahy, ale pouze stupně rozvoje „čistých dovedností“.20

20 V USA paradoxně právě velký zájem politiků o tuto problematiku brání formulaci závazného národního kurikula historie. 
Naše analýza má více limitů: patří k nim omezený počet studovaných příkladů a jejich malá kulturní variabilita. Dokonce i v rámci anglofonních zemí by šlo uvést případy jako Skotsko (Holec \& Dvořák, 2017) nebo Nový Zéland (Ormond, 2017), které se $v$ některých ohledech liší.

Popisujeme ideové a projektované kurikulum, jen výjimečně komentujeme implementaci, recepci či účinky dokumentů. Je to dáno charakterem našeho výzkumu a částečně i novostí kurikulárních rámců, které jsou vesměs teprve zaváděny. Prakticky ve všech sledovaných zemích existuje vedle závazného kurikula (resp. stručných doporučení v USA) také další blízká vrstva, kterou jsou autory kurikula publikované modelové lekce, které projektovou verzi (rámce) konkretizují a ilustrují (De Groot-Reuvekamp et al., 2014). Zcela zásadně mohou záměr tvưrců kurikula proměnit způsob (externího) hodnocení žáků (Ormond, 2011), učebnice a samozřejmě příprava a přístup učitelů (Stará \& Starý, 2017).

Také komparace má některá úskalí. Austrálie a USA jsou federacemi a námi zkoumané kurikulární rámce jsou $v$ nich dále specifikovány $v$ jednotlivých státech, zatímco $\vee$ Anglii již tato úroveň do hry nevstupuje. Také primární škola sice má mezinárodně platné vymezení, ale $v$ různých zemích se její rozsah a pojetí liší (viz príloha A). Americké standardy historie (1994) byly rozděleny na učivo pro ročníky 0.-4. a 5.-12., v Austrálii naproti tomu 0.-6.(7.) a 7.-10. Přímo si odpovídají formální struktura nového amerického standardu pro společenské vědy (výstupy po 2. a 5. ročníku) a členění anglického národního kurikula (kličová období).

Dějepis je také ve srovnání např. s fyzikou či matematikou specifický. Anglie se od sledovaných mimoevropských zemí liší nejen tím, jak se konstituoval národ, ale také tím, že národní historie ( $v$ užším smyslu) pokrývá odlišně dlouhá období. Tento rozdíl se týká hlavně třetí výzkumné otázky, kde by mohl částečně vysvětlovat anglickou preferenci lineárního osnování učiva; avšak jiné evropské země (např. Nizozemsko) také lineární osnování neuplatňují. Přes uvedená omezení doporučujeme dále se věnovat komparacím pojetí primární historie - např. sledovat další osud reforem v anglofonním světě a rozšíríit záběr o země kontinentální Evropy.

\section{Závěr}

Přímé srovnání s naší situací nebylo cílem naší studie, je však vždy v komparativní studii implicitně přítomno. Proto se ho na závěr stručně dotkneme. České rámcové vzdělávací programy (RVP) byly silně ovlivněny týmiž idejemi posilování autonomie učitele při výběru obsahu vzdělávání, které v předchozích dekádách ovlivnily školství např. v Austrálii. Stejně tak RVP ZV zvolilo poměrně krajní stanovisko nezávaznosti obsahu. Nedávné reformy však ukazují, že se popsané země snaží obnovit rovnováhu mezi autonomií a odpovědností učitele, mezi dưrazem na základní, oborové a nado- 
borové dovednosti, mezi konceptuálními, faktickými a procedurálními znalostmi, mezi multikulturní perspektivou a národní identitou. $V$ tom smyslu se domníváme, že prípadná revize českých rámcových dokumentů by se měla týkat i těchto základních východisek.

Ovšem při formulaci konkrétních doporučení pro české prostředí na základě popisu zahraničních trendů je nutná velká opatrnost. Některé proměny kurikulární politiky $v$ uvedených zemích nejsou ve shodě s vývojem oborovědidaktického myšlení, ale spiše odrážejí momentální agendu politiků. Zejména však ze shod či rozdílů mezi RVP ZV a jinými kurikuly vzniklými v minulých dekádách nelze usuzovat na podobnost skutečné výuky historie u nás a jinde. Proto přebírání zahraničních řešení, odrážejících jinou realitu, může být kontraproduktivní. Jakákoli budoucí revize kurikula by měla vycházet především z empirických poznatků o podobě a výsledcích výuky historie v českých primárních školách, které jsou dosud sporadické.

\section{Poděkování}

Autoři děkují anonymním recenzentům a kolegům Petru Najvarovi, Janě Staré a Elišce Walterové za připomínky a podněty k různým verzím rukopisu.

\section{Literatura}

Adamson, B., \& Morris, P. (2007). Comparing curricula. In M. Bray, B. Adamson, \& M. Mason (Eds.), Comparative education research: Approaches and methods (s. 263-282). CERC Studies in Comparative Education 19. Hong Kong: Comparative Education Research Centre.

Beneš, Z. (2011). Co je (dnes) didaktika dějepisu? Pedagogická orientace, 21(2), 193-206.

Beneš, Z., \& Gracová, B. (2015). Didaktika dějepisu: Mezi socializací jedince a jeho individuální výchovou. In I. Stuchlíková \& T. Janík (Eds.), Oborové didaktiky: Vývoj - stav - perspektivy (s. 289-326). Brno: MU.

Bloudková-Dvořáková, M. \& Dvořák, D. (2005). Společenskovědní vzdělávání. In V. Spilková et al., Proměny primárního vzdělávání $v$ ČR (s. 209-223). Praha: Portál.

Brundrett, M. (2015). Policy on the primary curriculum since 2010: The demise of the expert view. London Review of Education, 13(2), 49-59.

Čapek, V. (2005). Některé mezinárodní projekty a koncepce dějepisu ve škole. In R. Kožiak \& I. Nagy (Eds.), Acta historica Neosoliensia 8 (s. 217-229). Banská Bystrica: KH FHV UMB.

Černý, K., \& Šubrt, J. (2013). K problematice školní výuky dějepisu. In J. Šubrt \& J. Vinopal (Eds.), Historické vědomí obyvatel České republiky perspektivou sociologického výzkumu (s. 52-69). Praha: Karolinum.

Činátl, K., \& Pinkas, J., et al. (2014). Dějiny ve filmu. Film ve výuce dějepisu. Praha: Ústav pro studium totalitních režimů.

De Groot-Reuvekamp, M. J., Van Boxtel, C., Ros, A., \& Harnett, P. (2014). The understanding of historical time in the primary history curriculum in England and the Netherlands. Journal of Curriculum Studies, 46(4), 487-514.

Donnelly, K. (2005). Benchmarking Australian primary school curricula. Canberra: Department of Education, Science and Training.

Dvořák, D. (2012). Od osnov k vzdělávacím standardům. Praha: PedF UK. 
152 Dvořák, D. (2015). Proměny kurikulárního diskurzu: 0 aktérech, standardech a ledních medvědech. In D. Greger (Ed.), Srovnávací pedagogika: Proměny a výzvy (s. 101-117). Praha: PedF UK.

Dvořák, D., \& Dvořáková, M. (2010). Dějepis a vlastivěda - varianty vztahu v českých a zahraničních kurikulech. In J. Märc et al., Dějepisné výzvy mezioborovým vztahům (s. 45-55). Ústí nad Labem: FF UJEP.

Gracová, B., \& Labischová, D. (2012). Současná teorie a praxe dějepisného vzdělávání na školách. Pedagogická orientace, 22(4), 516-543.

Greger, D. (2015). Metodologie srovnávací pedagogiky ve světě, u nás a v kontextu této publikace. In D. Greger (Ed.), Srovnávací pedagogika: Proměny a výzvy (s. 59-63). Praha: PedF UK.

Guyver, R. (2011). Primary history: Current themes. In I. Davis (Ed.), Debates in history teaching (s. 18-29). London: Routledge.

Harris, R., \& Ormond, B. (2018). Historical knowledge in a knowledge economy - what types of knowledge matter? Educational Review, 1-17.

Havlůjová, H., \& Najbert, J., et al. (2014). Pamět' a projektové vyučování v dějepise. Praha: Ústav pro studium totalitních režimů.

Henderson, D. (2015). Introduction to point and counterpoint: What does the review of the Australian Curriculum mean for history? Curriculum Perspectives, 35(1), 49-51.

Holec, J., \& Dvořák, D. (2017). Curriculum for Excellence: Kurikulum založené na kompetencích a zkušenosti z jeho implementace. Pedagogika, 67(1), 56-77.

Hudecová, D. (2006). Analýza dějepisných vzdělávacích programů ve vybraných státech Evropy a její výsledky. Praha: PedF UK.

Huggins, M., \& Knight, P. (1997). Curriculum continuity and transfer from primary to secondary school: The case of history. Educational Studies, 23(3), 333-348.

Ježková, V., Dvořák, D., \& Chapman, Ch. (2010). Školní vzdělávání ve Velké Británii. Praha: Karolinum.

Jireček, M. (2014). Vývoj vyučovacího předmětu dějepis v letech 1918-2013. Brno: MUNI Press.

Labadie, A. L. R. (2011). The battle for national history standards. In M. S. Plakhotnik, S. M. Nielsen, \& D. M. Pane (Eds.), Proceedings of the Tenth annual college of education \& GSN research conference (s. 109-115). Miami: Florida International University. Dostupné z http://coeweb.fiu.edu/research_conference

Labischová, D. (2013). Co si uchováváme v paměti? Empirický výzkum historického vědomí. Ostrava: OU.

Labischová, D., \& Gracová, B. (2010). Příručka ke studiu didaktiky dějepisu. Ostrava: FF OU.

Levstik, L. S., \& Thornton, S. J. (2018). Reconceptualizing history for early childhood through early adolescence. In S. A. Metzger \& L. McArthur Harris (Eds.), The Wiley international handbook of history teaching and learning (s. 473-501). Hoboken: Wiley-Blackwell.

Lingard, B., \& McGregor, G. (2014). Two contrasting Australian Curriculum responses to globalisation: What students should learn or become. Curriculum Journal, 25(1), 90-110.

Maddison, M. (2014, jaro). The National curriculum for History from September 2014: The view from Ofsted. Primary History, 66, 5-7.

Mareš, J. (2017). Etická dilemata učitelů dějepisu aneb Jak vyučovat o kontroverzních obdobích dějin? Historie - otázky - problémy, 9(2), 35-55.

Ormond, B. M. (2011). Shifts in knowledge teaching: The unexpected consequences of assessment practices on secondary history. Pacific-Asian Education, 23(1), 5-22.

Ormond, B. M. (2017). Curriculum decisions - the challenges of teacher autonomy over knowledge selection for history. Journal of Curriculum Studies, 49(5), 599-619.

Pešková, K., Janko, T., Lupač, M., Ševčík, K., Doležal, T., Moravec, J., ... Češková, T. (2014). Kurikulum základní školy: Metodologické př́istupy a empirická zjištění. Brno: MU.

Priestley, M. , Laming, M., \& Humes, W. (2015). Emerging school curricula: Australia and Scotland compared. Curriculum Perspectives, 35(3). Dostupné z http://www.acsa.edu.au /pages/page33.asp 
Retz, T. (2016). At the interface: Academic history, school history and the philosophy of history. Journal of Curriculum Studies, 48(4), 503-517.

Ritzvi, F., \& Lingard. B. (2010). Globalizing education policy. London: Routledge.

Ross, E. W. , Mathison, S., \& Vinson, K. D. (2015). Social studies education and standards-based education reform in North America: Curriculum standardization, high-stakes testing, and resistance. Revista Latinoamericana de Estudios Educativos, 10(1), 19-48.

Savage, G. C., \& O'Connor, K. (2015). National agendas in global times: Curriculum reforms in Australia and the USA since the 1980s. Journal of Education Policy, 30(5), 609-630.

Schoenfeld, A. H. (2004). Math wars. Educational Policy, 18(1), 253-286.

Smith, J. (2017). Discursive dancing: Traditionalism and social realism in the 2013 English history curriculum wars. British Journal of Educational Studies, 65(3), 307-329.

Stará, J., \& Starý, K. (2017). Studie výuky dějepisného učiva na 1. stupni ZŠ. Pedagogická orientace, 27(1), 6-29.

Symcox, L., \& Wilschut, A. (Eds.). (2009). National history standards: The problem of the canon and the future of history teaching. Charlotte, NC: Information Age.

Štorchův memoriál (2013). Marginalia Historica, 4(2), 215-242.

Tambyah, M. (2015). What does the review of the Australian Curriculum mean for history in the primary years? Curriculum Perspectives, 35(1), 55-57.

Van der Leeuw-Roord, J. (2007). Two steps forwards, one step back: Sharing our stories and looking for the common threads. EUROCLIO Bulletin 26.

Walterová, E. (1994). Kurikulum: Proměny a trendy v mezinárodní perspektivě. Brno: CDVU.

Wilschut, A. (2009). Canonical standards or orientational frames of reference? The cultural and the educational approach to the debate about standards in history teaching. In L. Symcox $\&$ A. Wilschut (Eds.), National history standards: The problem of the canon and the future of teaching history (s. 113-135). Charlotte: Information Age Publishers.

Young, M. (2007). Bringing knowledge back in: From social constructivism to social realism in the sociology of education. London: Routledge.

Young, M., \& Muller, J. (2010). Three educational scenarios for the future: Lessons from the sociology of knowledge. European Journal of Education, 45(1), 11-27.

Zajda, J. (2015). Globalisation, ideology and history school textbooks: The Russian Federation. In Zajda, J. (Ed.), Nation-building and history education in a global culture (s. 29-50). Dordrecht: Springer.

Zakaria, F. (2016, 29. února). Centristé se drží. Respekt, 27(9), s. 15.

Analyzovaná kurikula:

Australian Curriculum, Assessment and Reporting Authority (ACARA). (2015). Australian Curriculum, v. 8.1. Dostupné z http://www.australiancurriculum.edu.au/humanities-and-social -sciences/hass/

Department for Education. (2013). National curriculum in England: History programmes of study. Dostupné z https://www.gov.uk/government/publications/national-curriculum-in -england-history-programmes-of-study

National Center for History in the Schools. (1994). National standards for history for grades K-4: Expanding children's world in time and space. Los Angeles: Author. Dostupné z http: / / www.nchs.ucla.edu/history-standards/standards-for-grades-k-4/

National Council for the Social Studies. (2013). The college, career, and civic life (C3) framework for social studies state standards: Guidance for enhancing the rigor of K-12 civics, economics, geography, and history. Silver Spring: NCSS. Dostupné z http: / /www.socialstudies .org/system/files/c3/C3-Framework-for-Social-Studies.pdf 
Příloha A

Primární vzdělávání (ISCED 1) ve sledovaných zemích

\begin{tabular}{|c|c|c|c|c|}
\hline Normativní věk & Anglie & Austrálie & USA & Česko \\
\hline Předchází & $\begin{array}{l}\text { early years / } \\
\text { foundation stage }\end{array}$ & $\begin{array}{l}\text { pre-school, } \\
\text { kindergarten }\end{array}$ & \multirow{2}{*}{$\begin{array}{l}\text { nursery school, } \\
\text { (pre)kindergarten } \\
\text { aj. }\end{array}$} & \multirow[t]{2}{*}{ mateřská škola } \\
\hline 5 & \multirow{4}{*}{$\begin{array}{l}\text { Key stage } 1 \\
\text { (infant) }\end{array}$} & & & \\
\hline 6 & & & & \multirow{3}{*}{$\begin{array}{l}\text { 1. stupeň základního } \\
\text { vzdělávání } \\
\text { 1. období }\end{array}$} \\
\hline 7 & & & & \\
\hline 8 & & primary school & $\begin{array}{l}\text { elementary school } \\
\text { nebo }\end{array}$ & \\
\hline 9 & \multirow{2}{*}{$\begin{array}{l}\text { Key stage } 2 \\
\text { (junior) }\end{array}$} & & grade school & \multirow{2}{*}{ 2. období } \\
\hline 10 & & & & \\
\hline 11 & \multirow[b]{2}{*}{$\begin{array}{l}\text { secondary school } \\
\text { Key stage } 3\end{array}$} & & & \multirow[b]{2}{*}{$\begin{array}{l}\text { 2. stupeň } \\
\text { základního } \\
\text { vzdělávání }\end{array}$} \\
\hline $\begin{array}{c}12 \\
\text { Následuje }\end{array}$ & & $\begin{array}{l}\text { (lower) } \\
\text { secondary } \\
\text { school }\end{array}$ & $\begin{array}{l}\text { middle / junior } \\
\text { high school }\end{array}$ & \\
\hline
\end{tabular}

Pozn.: V jednotlivých australských státech se hranice a délka (6-7 let) primární školy poněkud liší. Zdroj: UNESCO, nces.ed.gov. 


\section{Příloha B}

Rámcové výstupy oboru dějepis $v$ předškolním až 5 . ročníku v americkém společenskovědním standardu (National Council for the Social Studies, 2013)

\begin{tabular}{|c|c|}
\hline Na konci 2. ročníku & Na konci 5. ročníku \\
\hline \multicolumn{2}{|c|}{ změna, kontinuita a kontext } \\
\hline Vytvoří chronologickou řadu více událostí & $\begin{array}{l}\text { Vytvoří chronologickou řadu více vzájemně } \\
\text { provázaných událostí pro porovnání vývoje }\end{array}$ \\
\hline Porovná život v minulosti a dnes & $\begin{array}{l}\text { Porovná život v určitých historických obdobích } \\
\text { a dnes }\end{array}$ \\
\hline $\begin{array}{l}\text { Klade otázky o jedincích a skupinách, } \\
\text { kteří přispívali k historické změně }\end{array}$ & $\begin{array}{l}\text { Klade otázky o jedincích a skupinách, kteří } \\
\text { přispívali k významným historickým změnám } \\
\text { a kontinuitám }\end{array}$ \\
\hline \multicolumn{2}{|c|}{ perspektivy } \\
\hline \multirow[t]{2}{*}{$\begin{array}{l}\text { Porovnává perspektivu lidí v minulosti } \\
\text { a v současnosti }\end{array}$} & $\begin{array}{l}\text { Vysvětlí, proč se perspektiva různých jedinců/ } \\
\text { skupin žijících ve stejné historické době liší }\end{array}$ \\
\hline & $\begin{array}{l}\text { Vysvětlí souvislosti mezi historickými kontexty } \\
\text { a perspektivou lidí příslušné doby }\end{array}$ \\
\hline $\begin{array}{l}\text { Porovná různé zprávy o téže historické } \\
\text { události }\end{array}$ & $\begin{array}{l}\text { Vysvětlí, jak perspektivy lidí ovlivňují historické } \\
\text { prameny, které vytvářeli }\end{array}$ \\
\hline
\end{tabular}

\section{historické prameny a doklady}

Uvede různé druhy historických pramenů

Vysvětlí, jak lze historické prameny použít ke studiu minulosti

Určí autora, datum a místo původu historického pramenu z informací obsažených v pramenu samém

Vytváří otázky o určitém historickém zdroji z hlediska jeho vztahu ke konkrétní historické události nebo $\mathrm{k}$ vývojové změně

Shrne, jak se různé druhy historických pramenů užívají pro vysvětlení minulých událostí

Porovná informace poskytované různými historickými prameny o minulosti

Vyvodí účel vytvoření pramene a cílovou skupinu, pro niž byl určen, z informací obsažených $v$ pramenu samém

Vytváří otázky o souboru historických zdrojů z hlediska jejich vztahu ke konkrétním historickým událostem nebo k vývojovým změnám

Užíá informace o historickém pramenu (autor, datum a místo původu, účel jeho vytvoření, cílová skupina, pro niž byl určen), pro posouzení, nakolik je pramen užitečný pro studium určitého tématu

přičinná souvislost a argumentace

Navrhuje možné přičiny určité události nebo vývoje $v$ minulosti

Vybere, které prríčiny jsou pravděpodobnější než jiné pro vysvětlení historické události nebo vývoje
Vysvětlí pravděpodobné příčiny historických událostí nebo vývoje

Používá doklady k rozvinutí tvrzení o minulosti

Shrne ústřední myšlenku sekundárního historického pramene 
Australské primární kurikulum pro humanitní a sociální vědy (zkráceno, parafrázováno)

\begin{tabular}{|c|c|c|}
\hline Ročník & $\begin{array}{l}\text { Společenskovědní } \\
\text { téma }\end{array}$ & Dějepisný obsah \\
\hline 0. & Můj osobní svět & Rodina, rodinná historie, památky, které ji ukazují \\
\hline 1. & $\begin{array}{l}\text { Jak se můj svět liší od } \\
\text { minulosti a jak se může } \\
\text { změnit v budoucnosti }\end{array}$ & $\begin{array}{l}\text { Nedávná minulost a blízká budoucnost v kontextu žákova } \\
\text { světa } \\
\text { Kontinuita a proměna rodinných struktur a rolí } \\
\text { Změny dětství: prarodiče, rodiče, žáci } \\
\text { Výrazy vyjadřující čas, př́tomnost, minulost a budoucnost, } \\
\text { osobně významné dny a události (narozeniny, oslavy, roční } \\
\text { období) }\end{array}$ \\
\hline 2. & $\begin{array}{l}\text { Komunita - Náš vztah } \\
\text { k minulým a současným } \\
\text { lidem a místům }\end{array}$ & $\begin{array}{l}\text { Historie významné osoby, budovy, ekosystému v naší } \\
\text { komunitě, co nám říká o minulosti } \\
\text { Dnešní význam kulturní nebo duchovní památky } \\
\text { Dopad proměn technologie na život lidí (domácnost, práce, } \\
\text { cestování, komunikace, hra) }\end{array}$ \\
\hline
\end{tabular}

3. Různost komunit a míst Význam konkrétního místa či krajiny pro místní Aboridžince a jejich př́nos Proměny a kontinuita místní komunity a prínos lidí různého původu $\mathrm{k}$ jejímu vývoji a charakteru Svátky slavené v Austrálii, význam symbolů a znaků Svátky a vzpomínkové dny na různých místech světa (např. čínský nový rok v Asii, pád Bastily ve Francii, Den nezávislosti v USA) a ty, které se připomínají i v Austrálii (vánoce, diwali, velikonoce, chanuka, ramadán...)

4. Vzájemné ovlivňování Různost prvních obyvatel Austrálie a jejich dlouhodobé mezi lidmi, místy a prírodní prostředími spojení s určitými krajinami a místy (země, moře, vodní cesty, obloha...)

$v$ minulosti

a současnosti Př́běh nejméně jednoho objevitele či cestovatele (do konce 18. století) a jeho kontakty s jinými společnostmi a jejich důsledky Příběh prvních evropských osadníků (kdo a proč cestoval, jejich zkušenosti po př́ijezdu)

Charakter kontaktů mezi Aboridžinci a jinými skupinami, jejich důsledky

5. Australské komunity - Austrálie v 19. století jejich minulost, přitomnost a možná Ekonomické, politické a sociální důvody vzniku britských kolonií v Austrálii budoucnost Trestanci a kolonisté, jejich vliv na zemi a původní obyvatele, proměna životního prostředí Dopad významné události nebo inovace na konkrétní kolonii Příčiny imigrace a dopad konkrétní skupiny na kolonii Vliv významné osobnosti nebo skupiny na kolonii 
6. Austrálie $v$ minulosti Klíčové události, osobnosti a myšlenky, které vedly $\mathrm{k}$ vzniku a současnosti a její australské federace a ústavy propojení s různorodým Vývoj australské demokracie a občanství, včetně postavení světem a práv Aboridžinců, imigrantů, žen a dětí Př́běhy a motivy různých skupin novodobých imigrantů (včetně jedné skupiny pocházející z Asie)

Př́nos jedinců a skupin k vývoji Austrálie ve 20. století

RNDr. Dominik Dvořák, Ph.D., Ústav výzkumu a rozvoje vzdělávání Univerzita Karlova, Pedagogická fakulta Myslíkova 7, 11000 Praha dominik.dvorak@pedf.cuni.cz

Ing. Michaela Dvořáková, Ph.D., katedra občanské výchovy a filozofie Univerzita Karlova, Pedagogická fakulta Magdaleny Rettigové 4, 11639 Praha michaela.dvorakova@pedf.cuni.cz 